$12-21-2020$

\title{
Cambodian Family Albums: Tian's "L'année du lièvre"
}

Angelica P. So

Emory University

Follow this and additional works at: https://digitalcommons.usf.edu/gsp

\section{Recommended Citation}

So, Angelica P. (2020) "Cambodian Family Albums: Tian's "L'année du lièvre"," Genocide Studies and Prevention: An International Journal: Vol. 14: Iss. 3: 90-109.

DOI:

https://doi.org/10.5038/1911-9933.14.3.1734

Available at: https://digitalcommons.usf.edu/gsp/vol14/iss3/9

This Articles is brought to you for free and open access by the Open Access Journals at Digital Commons @ University of South Florida. It has been accepted for inclusion in Genocide Studies and Prevention: An International Journal by an authorized editor of Digital Commons @ University of South Florida. For more information, please contact digitalcommons@usf.edu. 


\title{
Cambodian Family Albums: Tian's "L'année du lièvre"
}

\author{
Angelica P. So \\ Emory University \\ Atlanta, Georgia, USA
}

\section{Introduction}

Franco-Cambodian cartoonist Tian's three-volume graphic novel, L'Année du lièvre (2011-2016), recently released in English as Year of the Rabbit in a three-part single volume (2020), provides witness to the events of the Cambodian Genocide from 1975-1979 in Cambodia. ${ }^{1}$ The graphic novel, recounted through the eyes of Tian's father, Khim, documents his family's multiple escapes from death under the Khmer Rouge and Vietnamese Occupation, as well as in the Khao-I-Dang refugee camp on the Cambodian-Thai border. L'Année du lièvre also addresses the initial hearings against Khmer Rouge leaders in the 2009 Tribunal, and preserves family memories from pre-1975 Cambodia, and his family's resettlement in France in 1980 in the form of hand-drawn photographs and photo albums.

This article seeks to demonstrate the dual function of L'Année du lièvre as what I call a "Cambodian family album," or a personal-collective archive used to transfer to subsequent generations of the history of the Cambodian genocide; the collective memories of pre-1975 Cambodia which precede the Khmer Rouge takeover of Phnom Penh; and the Cambodian humanitarian crisis and exodus of the 1970s-1990s. The conceptualization of the family album is derived from the literal translation, from Khmer into English, of the term "photo

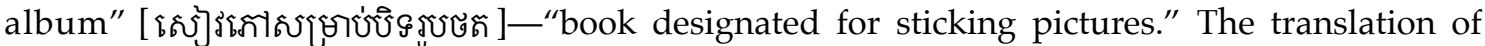
the term emphasizes the fragmentary and creative nature of postmemory, or the secondgeneration's experience of their parents' trauma. Memory studies scholar Marianne Hirsch's concept of postmemory-originally conceived with second-generation Holocaust survivors in mind-aptly applies to 1.5- and second-generation Cambodian genocide survivors: "Postmemory characterizes the experience of those who grow up dominated by narratives that preceded their birth, whose own belated stories are evacuated by the stories of the previous generation shaped by traumatic events that can be neither understood nor recreated." 2 The testimonial quality of Tian's L'Année du lièvre is characteristic of autobiographical comics, especially those used to recount genocide, trauma, and displacement such as GB Tran's Vietnamerica (2010), Marjane Satrapi's Persepolis (2000), and Art Spiegelman's Maus (1980; 1991). ${ }^{3}$ Comics scholar Elisabeth El Refaie defines autobiographical comics as "a loose category of life writing through the use of sequential images and (usually) words." 4 Other comics scholarsnotably Hillary Chute, Andrew Kunka, and Frederik Byrn Køhlert-have also emphasized the testimonial aspect of autobiographical comics, in which the reader participates as witness. While Tian's graphic novel fits the genre of autobiographical comics, this article reads L'Année du lièvre as a family album in order to demonstrate how the Cambodian family album exceeds

\footnotetext{
1 Tian, L'Année du lièvre: Au revoir Phnom Penh (Paris: Gallimard, 2011); Tian, L'Année du lièvre: Ne vous inquiétez pas (Paris: Gallimard, 2013); Tian, L'Année du lièvre: Un nouveau départ (Paris: Gallimard, 2016); Tian Veasna, Year of the Rabbit (Montreal: Drawn and Quarterly, 2020).

2 Marianne Hirsch, Family Frames: Photography, Narrative, and Postmemory (Cambridge: Harvard University Press, 1997), 22. See also Ibid., 243-245.

${ }^{3}$ Hillary L. Chute, Disaster Drawn: Visual Witness, Comics and Documentary Form (Cambridge: Belknap Press, 2016$), 157$. See also Laurike in't Veld, The Representation of Genocide in Graphic Novels: Considering the Role of Kitsch (Cham: Palgrave Macmillan, 2019), 16. For graphic novels, see GB Tran, Vietnamerica: A Family's Journey (New York: Villard Books, 2010); Marjane Satrapi, Persepolis (Paris: L'Association, 2000); Art Spiegelman, Maus I: A Survivor's Tale: My Father Bleeds History (New York: Pantheon, 1980); Art Spiegelman, Maus II: A Survivor's Tale: And Here My Troubles Began (New York: Pantheon, 1991).
}

4 Elisabeth El Refaie, Autobiographical Comics: Life Writing in Pictures (Jackson: University Press of Mississippi, 2017), 48; Andrew J. Kunka, Autobiographical Comics (New York: Bloomsbury Academic, 2018), 10. 
categorization; in other words, family albums can be autobiographical comics, but not all autobiographical comics can be family albums. This article begins with an analysis of the graphic novel as family album and moves beyond the comics medium and sequential art format to show how Cambodian identity is being reshaped and renegotiated through what I call "Cambodian new aesthetics." The family album is thus considered more broadly and beyond the medium of comics and argues that second-generation survivors take on an active role in the process of (post)memory work through new and imaginative aesthetic forms. In closing, this article considers the ways in which Franco-Cambodian and Cambodian-American artists such as Franco-Cambodian filmmaker Denis Do, Cambodian-American choreographer Prumsodun Ok, and Cambodian American poet Kosal Khiev contribute to redefining Cambodian identity in the 21st century.

\section{Reading the Graphic Novel as a Family Album}

Like the survivors of the Khmer Rouge regime, photos, memories, and keepsakes that existed before the 1980s outlasted their intended destruction and continue to act as tools to recount

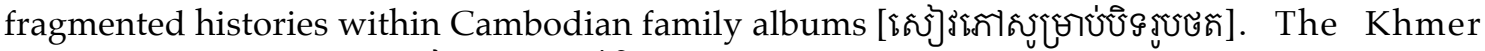

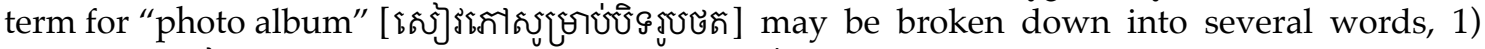

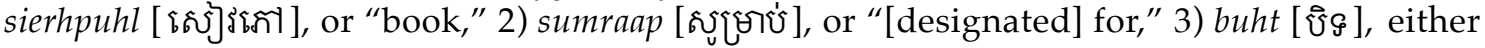
"to close," "to stick/ to glue," or "closed/blocked off," 4) ruup [รู่ ], or "portrait," or "photo," 5)

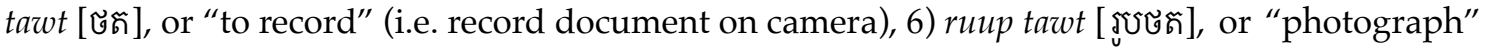
(reversing the words, tawt ruup, would mean "to take a picture"). The family album, or "book designated for sticking pictures," thus suggests an invitation to enclose memories in the bookrather than to close the book. The specificity of Cambodian postmemory may be illustrated through the term buht [ชิ§] in the photo album, or the family album. In Khmer, the word, buht [ชิ९], has multiple meanings: Buht can mean "to close" or "to be closed," or indicate that something is walled off and inaccessible. Yet, it can also refer to the act of gluing or sticking. The latter contradicts the act of closing, but both meanings in Khmer function to depict the creative process of memory work. The function of buht in the expression "photo album" emphasizes the creative act of assembling and fastening memories in a book. It is then, the act of collating and gluing the fragments of "disparate sources" that generates and produces memory. 5

The album, comprised of three volumes, contests the notion of 1975-1979 as a past history and buried memory. In addition to enclosing within the album the narrative of his own family's survival in Democratic Kampuchea, Tian communicates where his family members settled after 1980 (France and Canada), within a supplemental family album, at the close of the trilogy. In doing so, Tian transmits to the reader the history of the Cambodian exodus, and the Cambodian Diaspora, in the three volumes, published in 2011, 2013, and 2016. Within L'Année $d u$ lièvre, the reader witnesses the narrator's birth, near-death, and symbolic rebirth in France. The overlap of the year of the author's birth, 1975, with the historical association of 1975 with the Khmer Rouge takeover of Cambodia, reveals the impossibility of separating the personalfamilial history from the larger History. ${ }^{6}$ In particular, the figure of le lièvre, alludes to the

${ }^{5}$ James E. Young, The Texture of Memory: Holocaust Memorials and Meaning (New Haven: Yale University Press, 1993), xixii.

6 The boundaries between the dual meanings of "histoire" in French ("story" and "history") are often blurred. The uppercase " $h$ " in History refers to the chronicle sense of the term; the lowercase " $h$ " alludes to a personal narrative. The overlap between the history of Democratic Kampuchea and Chan Veasna's autobiographical tale is depicted via the author's birth in Volume 1. See Tian, Au revoir Phnom Penh, 42; Veasna, Year of the Rabbit, 53. The trilogy closes with a birth announcement, at the entrance-exit of the Khao-I-Dang Refugee Camp. The final panel depicts a family of four, framed by two tailless speech balloons. The balloon on the left-hand side of the panel reads: "Une nouvelle vie en France allait s'offrir à nous! Et en cadeau..." To the right, the text reads: "Nous allions avoir un petit frère pour Chan." [We would be able to start a new life in France. And as a bonus...Chan would have a little brother.] See Tian, Un nouveau départ, 110; Veasna, Year of the Rabbit, 368. 
trickster rabbit in Cambodia's oral and written folktales. ${ }^{7}$ Additionally, the rabbit's wit-used to escape death countless times-reflects Tian's survival story. Much like Br'er rabbit and trickster tales from Africa, the Caribbean, and the U.S. South, ${ }^{8}$ Cambodian folktales are inundated with the cunning hare that uses its wits to outsmart others. Khmer linguist Chhany Sak-Humphry stresses the importance of the hare as hero in Cambodian culture, and includes the following stories, in her compilation of Khmer folktales, Tales of the Hare, which include: "How the Hare, Caught in a Snare, Escaped (\& Rescued Some Fish!)," "How the Hare Escaped the Jaws of the Crocodile," "How the Hare Punished the Crocodile for Seeking Revenge," "How the Hare Rescued a Man and Punished the Crocodile," "Judge Hare and the Fish Trap in the Tree," "How Judge Hare Helped a Man Get His Wife Back," and "How the Hare Tricked a Spirit."9 Judith Jacob also notes that the rabbit is "Brer Rabbit in a different setting," emphasizing his ability to "[escape] from death over and over again." ${ }^{10}$ Thus, Tian's Cambodian Family Album not only reproduces but, as I would argue, creates and reconstructs Cambodian memories-including the literary and oral histories preceding 1975-1979-and reimagines the trickster rabbit in the form of repeated survival tests depicted in his family album. Even for survivors of the genocide, the repetition of an escape from death follows them in the form of survivor's guilt, or in what Shoshana Felman and Dori Laub call a second holocaust, upon re-experiencing a traumatic event. 11

The title of the trilogy, L'Année du lièvre, is engraved in the Cambodian collective memory as the beginning of the Cambodian Genocide. The takeover of Phnom Penh starts the three-volume narrative and precedes the author's birth in the graphic novel. The very first page of the trilogy depicts a framed, full-page panel. Beneath the chapter heading, a representation of faceless men standing on a tank with raised fists, guns, and flags, is accompanied with the caption, "LE GLORIEUX 17 AVRIL 1975."12 The family album thus begins with a familiar illustration of The Fall of Phnom Penh which appears similar to the historical recounting of the Cambodian genocide. In particular, the album opens with the monumentalization of 1975 as a historical event. The caption, which is written in capital letters, "LE GLORIEUX 17 AVRIL 1975," mimics the inscription of tombstones, and commemorative plaques. Moreover, the Khmer Rouge takeover mirrors the domination of Tian's personal history and memory of 1975. 1975-the start of the erasure of time and the entry into the Year Zero-also overshadows Cambodians' celebration of the New Year. ${ }^{13}$ The flashbulb memory of the Cambodian Genocide — synonymous with the Fall of Phnom Penh to the Khmer Rouge, April 17, 1975-nearly overlaps with the three-day celebration of the Cambodian New Year. In Khmer, Chaul Chnam

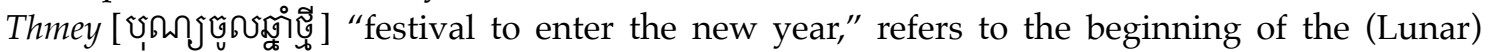
New Year, typically celebrated on April 13-14. The New Year comprises an important part of Cambodian culture, and Cambodians of the Diaspora associate the date with the New Year. Yet, the commemoration of the Fall of Phnom Penh, and the Khmer Rouge takeover of Cambodia on April 17, 1975 overshadows Cambodian New Year as well as the other cultural and historical

\footnotetext{
7 Also worth noting is the representation of Jews as mice in Art Spiegelman's Maus. See Art Spiegelman, Maus I: A Survivor's Tale: My Father Bleeds History (New York: Pantheon, 1986); Spiegelman, Maus II: A Survivor's Tale: And Here My Troubles Began (New York: Pantheon, 1991).

${ }^{8}$ Margaret P. Baker, "The Rabbit as Trickster," Journal of Popular Culture 28, no. 2 (1994), 149. See also, Ashleigh Harris, "Speaking the 'Truth' by Dissembling': Necessary Ambiguities in the Tar-Baby Tale," Journal of Literary Studies (Pretoria, South Africa) 16, no. 3-4 (2000), 61, accessed Nov. 13, 2020, https://doi.org/10.1080/02564710008530265.

9 Chhany Sak-Humphry, Tales of the Hare: 27 Classic Folktales from Cambodia, ed. Kent Davis (Holmes Beach: DatASIA, 2010).

${ }^{10}$ Judith M. Jacob, The Traditional Literature of Cambodia: A Preliminary Guide (Oxford: Oxford University Press, 1996), 16.

${ }_{11}$ Shoshana Felman and Dori Laub, Testimony: Crises of Witnessing in Literature, Psychoanalysis, and History (London: Routledge, 1991), 65.

12 Tian, Au revoir Phnom Penh, 1; Veasna, Year of the Rabbit, 13.

${ }^{13}$ In his graphic novel, Impasse et Rouge, Franco-Cambodian graphic novelist and Cambodian Genocide child survivor Séra also recounts the Khmer Rouge occupation of Phnom Penh while referring to the New Year of the Hare on Monday, April 14, 1975. See Séra, Impasse et Rouge (Paris: Albin Michel, 2003), 24.
} 
traits of Cambodia that precede and follow 1975-1979. The historical date of la chute de Phnom Penh (the Fall of Phnom Penh) thus affects how future New Year celebrations will be shaped by the memory of the genocide. In particular, the overlapping events come to resemble the cyclical nature of a traumatic repetition compulsion: The birth of a (new) year is also synonymous with the death of a city and nation-the beginning of genocide. Time and chronologizing history are further complicated considering the Khmer Rouge's erasure of time and restarting of the clocks to Year Zero. ${ }^{14} 1975$ thus marks the start of its own erasure. The pre-Democratic Kampuchea15 form of keeping time would not return to Cambodia until 1979. Thus, L'Année du lièvre belatedly writes into history the erasure of the historical records preceding 1979. Though Tian cannot separate 1975 from his own history, the creation of the H/historical Cambodian Family Album can be read as a conscious attempt of reclaiming his and Cambodia's history beyond the containment of 1975-1979. Moreover, L'Année du lièvre represents "the conflation of private and public memory." 16 What appears as crystalized and an illustration of a historical record transforms, especially in Volume 3, into a commemorative album that finds itself in-between private and public art-past and present memory. Young's reflections on the memory-work from the Holocaust context may be applied here to Tian's graphic novel.

Instead of allowing the past to rigidify in its monumental forms, we would vivify memory through the memory-work itself-whereby events, their recollection, and the role monuments play in our lives remain animate, never completed. In this light, we find the performance of the Holocaust memorials depends not on some measured distance between history and its monumental representations, but on the conflation of private and public memory, in the memorial activity by which minds reflecting on the past inevitably precipitate in the present historical moment. ${ }^{17}$

By the close of Volume 3, Un nouveau départ, the album re-opens itself, through the inclusion of a supplemental family album, entitled "Un nouveau départ après 1980."18 Rather than closing the three-volume album with a linear recounting of the Khmer Rouge history, the narrative moves forward, and beyond, with Tian's family's renaissance. In a 2011 podcast interview with France Culture, Tian-who spent the first five years of his life in displacement from 1975 to 1980-notes that he has few memories of his childhood. His creation of L'Année du lièvre enabled him to trace his forgotten history.

J'ai eu très peu de souvenirs de mon enfance. Je les ai retrouvés en réalisant cette bande dessinée, L'année du lièvre. Et du coup, quand j'étais petit, j'avais beaucoup de souvenirs en France. Donc, j'avais l'impression que ma naissance a commencé dès que je suis arrivé en France. [I had very few memories from my childhood. I found them by creating this graphic novel, Year of the Rabbit. And when I was little... I had many memories in

\footnotetext{
14 See François Ponchaud, Cambodge, Année Zéro: Document (Paris: Julliard, 1977), 29-36.

15 The use of Kampuchea, here, refers to Communist Party of Kampuchea (CPK), and the Khmer Rouge takeover of Cambodia during the period of 1975-1979. See Khamboly Dy, A History of Democratic Kampuchea (1975-1979) (Phnom Penh: Documentation Center of Cambodia, 2007), 1-2.

16 Young, The Texture of Memory, 15.

17 Ibid.

18 "Un nouveau départ après 1980" is included at the end of Volume 3. It takes the form of a chapter but isn't labeled as one. The pages in "Un nouveau départ après 1980" are left unnumbered, but it immediately follows page 110. See Tian, Un nouveau départ, page after 110. See also chapter "A New Beginning-1980 and beyond," in Veasna, Year of the Rabbit, page after 368 .
} 
France, so I felt as though my birth began as soon as I arrived in France. $]^{19}$

The desire to forget and to begin anew is a common and shared experience in firstgeneration, and child survivors of the 1.5 generation. Tian's association of his birth with his arrival in France is comparable to filmmaker Rithy Panh's experience as a child survivor. ${ }^{20}$ Tian and Séra's graphic novels, and Panh's films reconstruct and reframe history from the point of and for members of the Cambodian Diaspora. The graphic novel, like film, offers the possibility of freeing oneself of the weight of the past and lingering unconscious memories. It is worth noting that Franco-Cambodian artist and Cambodian Genocide child survivor Séra (Phousséra Ing) was the first graphic novelist to visually narrate the personal and collective traumas of the Cambodian genocide, in Impasse et rouge (1995). ${ }^{21} \mathrm{He}$ also recounts the Khmer Rouge occupation of Phnom Penh while referring to the New Year of the Hare on Monday, April 14, 1975 in his graphic novels, L'Eau et la terre: Cambodge, 1975-1979 (2005), Lendemains de cendres: Cambodge, 1979-1993 (2007), and Concombres amers: les racines d'une tragédie, Cambodge, 1967-1975 (2018).22 Tian's L'Année du lièvre, however, is the first Franco-Cambodian graphic novel intended as a trilogy. While both 1.5-generation graphic novelists, Tian and Séra, visually recount the atrocities of the Cambodian genocide in the graphic novels, their styles are vastly different. Séra's photo-realistic style and use of somber colors to capture the violence of the Cambodian genocide differ from Tian's cartoonish style and juxtaposition of pastels with shades of black. As genocide scholar Caroline D. Laurent notes, the spatial layout of L'Année du lièvre allows for an active reader participation. ${ }^{23}$ The reader's active involvement in the reading/viewing process emphasizes the collaborative and creative aspect of the postmemorial album. In "Un nouveau départ après 1980," Tian inscribes into the sub-album the following encounter with his mother. Turned towards his mother, Tian asks, "Alors, maman, tu l'as lu?," [So, Mother, have you read it?] to which she responds, with the album in her hands: "J'ai essayé, mais je n'ai pas réussi à dépasser le 3e chapitre. Ça doit correspondre à ta naissance..." [I tried, but I could not get past the third chapter. That must be around the time of your birth...] Tian's mother thus closes the album prematurely before her son's belated rendering of his own birth. ${ }^{24}$ The seemingly contradictory overlap between premature and belated experiences of memory reflect Tian's status as being a member of the 1.5 generation, which is characterized by both "premature bewilderment and helplessness." 25

19 All transcriptions in French and translations into English are my own. Caroline Broué and Hervé Gardette, “Cambodge," September 14, 2011, in France Culture, podcast, 87 mins, accessed November 9, 2020, https:// www.franceculture.fr/emissions/la-grande-table-1ere-partie/cambodge.

20 Panivong Norindr, "The Sounds of Everyday Life in Rithy Panh's Documentaries," French Forum 35, no. 2-3 (2010), 183, accessed October 29, 2020, https:// doi.org/10.1353/frf.2010.0004; see also, Rithy Panh, dir., L'image manquante (ARTE Éditions, 2013), $92 \mathrm{~min}$.

21 Séra, Impasse et Rouge.

22 Ibid.; Séra, Concombres amers: les racines d'une tragédie, Cambodge, 1967-1975 (Vanves: Marabout, DL, 2018); Séra, L'eau et la terre: Cambodge, 1975-1979 (Paris: Delcourt, 2005); Séra, Lendemains de cendres: Cambodge, 1979-1993 (Paris: Delcourt, 2007).

23 Caroline D. Laurent, "(Re)creating the Past: Representations of Cambodia in Francophone Sequential Art" (Panel discussion at the 14th Biennial Conference of the International Association of Genocide Scholars, Phnom Penh, Cambodia, July 14-19).

24 "Un nouveau depart" is a 7-page narrative enclosed within—and immediately following-Volume 3. All of the pages are left unnumbered. The first page of "Un nouveau depart" is opposite page 368 in the English version and opposite page 110 in Vol. 3 in the French version. See Tian, Un nouveau départ, page after 110; Veasna, Year of the Rabbit, page after 368 .

${ }^{25}$ Susan Rubin Suleiman, "The 1.5 Generation: Thinking About Child Survivors and the Holocaust," American Imago 59, no. 3 (2002), 277. 


\section{Family Uprooting Under the Khmer Rouge Regime}

What I refer to as the "Khmer Rouge Family Album" appears briefly within the greater Cambodian Family Album. Situated at the halfway point of Volume 1, Au revoir Phnom Penh, and immediately following the chapter dedicated to the memory of the author's birth, Chapter 4, "Angkar," the Khmer Rouge Family Album emphasizes its place within the Cambodian common memory without becoming the dominant narrative. The juxtaposition of the two albums is observable through the Chapter 3 and 4 titles, "Veasna," and "Angkar." The reader witnesses the birth of Chan Veasna, the author known as Tian, in the village of Ta Prom. The Chan tree, to which the author owes his name, reappears throughout the chapter and stands over Chan and his family as a protector. His name reveals his family's attempt to merge his past and future destiny: "Chan Veasna, Chan c'est le nom de cet arbre qui pousse tout près de la cabane et Veasna veut dire destin, en espérant que sa vie sera heureuse." [Chan Veasna, Chan is the type of tree outside the hut, and Veasna means destiny, in the hope that he'll have a happy life. ${ }^{26}$ Chan's birth in 1975 occurs on Democratic Kampuchean soil-the site of mass murder and destruction-but the Chan tree, deeply rooted in the soil and watching over Chan Veasna's family, pre-dates the Communist Party of Kampuchea. Chan's parents attempt to override their misfortune by naming their child after the tree. Moreover, Chan's shared birth-place and time with the historical event of 1975 indicates that his personal-family album is also a survival tale in which generation occurs from destruction. Moreover, the author's birth, which occurs alongside the Chan tree, on Democratic Kampuchean soil, functions as a part of the endless Buddhist life cycle of life-death-rebirth. ${ }^{27}$

The visual and verbal play on cultivation-in the form of the Chan tree in Volume 1, and the family trees in Volumes 2 and 3-as well as the visual and verbal depictions of Khmer Rouge ideology of uprooting in Volumes 1-3 speak to the themes of survival and destiny. ${ }^{28}$ The subsequent chapter following the birth of Chan Veasna must be considered in regard to its

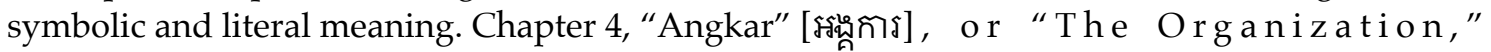

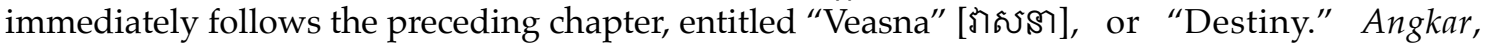
which refers to the leaders of the Communist Party of Kampuchea, can be interpreted in at least two ways: The political organization controlling Democratic Kampuchea, and the structured act of organizing, ordering, and arranging.

The Khmer Rouge Family Album reads as a separate narrative a part of the trilogyAlbum: It interrupts the reading process, visually and narrative-wise. The uniformed panels, minimalistic design, and use of gutters-which appear for the first and only time throughout the trilogy-complement Angkar's fixation on organization and structure. The Khmer Rouge Family Album is limited to two pages, in which each page includes clearly defined gutters used to separate three tiers of two panels. ${ }^{29}$ In the two-page spread, Khmer Rouge propaganda is succinctly exclaimed in each panel; the outline of Angkor Wat, and dramatic red shading, is repeated to symbolize Democratic Kampuchea, blood, and communism. Remaining true to The Angkar's "faceless" organization, the Khmer Rouge members are featured without any facial features, aside from the mouth-which is either represented by a single line in the form of a smile or a neutral expression, or a left- or right-angle bracket used to indicate a mouth agape. 30 While it is tempting to separate it from the rest of the whole of Tian's Cambodian Family Album, the history of destruction must be read as a part of the History of family memories and survival.

\footnotetext{
26 Tian, Au revoir Phnom Penh, 42; Veasna, Year of the Rabbit, 54.

27 Tian, Au revoir Phnom Penh, 41-42; Veasna, Year of the Rabbit, 53-54.

28 The family trees are included in the front matter of volumes 2 and 3, in the original French edition. In the English edition, the first family tree follows the preface, and the second family tree follows the postface. Note: These pages are unnumbered in both editions.

29 Tian, Au revoir Phnom Penh, 49-50; Veasna, Year of the Rabbit, 61-62.

30 Ibid.
} 
Volume 2, Ne vous inquiétez pas, expands on the Khmer Rouge's attempts of suppressing genealogical family ties under Angkar. The recurring appearance of trees throughout the volume stands against Angkar's intentions of uprooting and eradicating Cambodian genealogy, culture, and identity. Like the Khmer Rouge Family Album in Volume 1, Tian demonstrates the Communist Party of Kampuchea (CPK) ideology by inserting into the narrative an organizational chart of Angkar's classless hierarchy. ${ }^{31}$ At first, the organizational chart appears to contest the author's family trees-which the reader encounters in a two-page spread at the start of Volumes 2 and 3; yet, after reading the organizational chart in relation to the Khmer translation of "organizational chart" and "destiny," the Khmer Rouge and Cambodian Family Albums merge together. The top of the chart, labeled "Angkar," and represented by a monstrous and watchful eye, replaces the protective Chan tree represented in Volume 1. The redundancy of the "organization" appears in the translation of Angkar: it also sprouts from the tentacle of the watchful eye in the form of a speech balloon that reads, "Tout est organisé [...]," or "Everything is organized," and manifests itself in the form of an organizational chart. 32 Translating the Khmer expression for "organizational chart" reveals the Khmer Rouge's

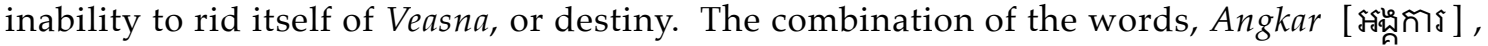
"organization," and leik [îชి], which means "number", as well as "position" and "rank," forms angkar leik [รรณू็การโญช ], or "organizational chart." Yet, leik also refers to what could be translated into English as "destiny," "chance," or "fortune." For instance, in colloquial Khmer, to have a

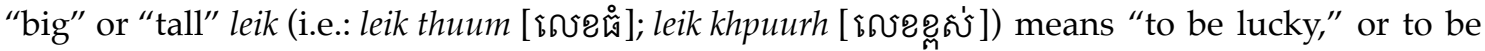
blessed with a good destiny. Thus, the organizational chart that represents Angkar in Chapter 3

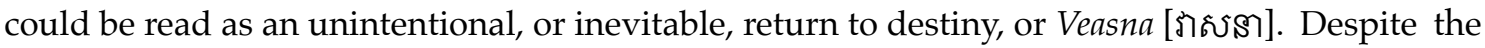
Khmer Rouge's attempt of writing over Khmer genealogy and suppressing familial ties, the Chan tree persists despite its ordered destruction.

Throughout the trilogy, Tian juxtaposes the Khmer Rouge slogans and Angkar's organized massacres with Cambodian proverbs, symbols of cultivation, Veasna, and survival. Reading the Khmer Rouge slogan in all uppercase letters: “COUPER UNE MAUVAISE HERBE NE SUFFIT PAS, IL FAUT LA DÉRACINER" [Cutting a weed is not enough—it must be pulled up by the roots] —against the Khmer proverb: "Il faut planter le kapokier puis le palmier" - the Cambodian Family Album offers an alternative memory of persistence, and escapes typical victim narratives. ${ }^{33}$ The Khmer Rouge slogan in capital letters highlights the extremism of Angkar's ideology. The metaphor of cultivation must be considered in relation to Cambodian agricultural history-from the Khmer Empire, and the Democratic Kampuchea regime-in order to demonstrate the role of production and peasantry in the Khmer Rouge's recruitment strategies and self-definition. Historian David Chandler notes that between 1945-1979, the final years of French colonial rule and the end of the Democratic Kampuchea, "some four-fifths of the population were farmers." 34 While it is known that the Communist Party of Kampuchea's recruitment strategy entailed targeting poor peasants, the role of French archaeologists' influence on the CPK ideology is often overlooked. The Khmer Rouge's fixation on rice cultivation and the peasantry is in part due to the circulation of the "intensive irrigation theory," 35 which historian Ben Kiernan describes as "the view of French archaeologists and

\footnotetext{
31 Tian, Ne vous inquiétez pas, 34; Veasna, Year of the Rabbit, 170.

32 Ibid.

33 The expression, "Il faut planter le kapokier puis le palmier" [One must plant the kapok tree] is the equivalent to the proverb, "See no evil, hear no evil, speak no evil." Yet, it also implies that in order to survive, one must plant Kapok and palm trees around the house. See Tian, Au revoir Phnom Penh, 76; Veasna, Year of the Rabbit, 88. See also, Tian, Au revoir Phnom Penh, 103; Veasna, Year of the Rabbit, 239.

34 David P. Chandler, The Tragedy of Cambodian History: Politics, War, and Revolution since 1945 (New Haven: Yale University Press, 1991), 4.

35 Ibid.
} 
scholars who pioneered study of the 'lost world' of medieval Khmers." 36 According to Kiernan, the theory, which was responsible for the old Khmer Empire's economic wealth, "was accepted as fact until the 1980s." 37 The Khmer Rouge ideology of the 1970s—which included "abolishing class distinctions, destroying prerevolutionary institutions, and transforming the population into unpaid agricultural workers"-is thus connected to pre-Democratic Kampuchean, and French colonial history. ${ }^{38}$

Reading the plant metaphor in the Democratic Kampuchea context reveals that élagage (pruning), and the removal of weak and damaged branches in order to promote the general health of the tree is insufficient to the rebuilding of Kampuchea. Angkar's role as the "mother and father" 39 to the Khmer people under the Khmer Rouge regime would thus entail a radical uprooting, rather than pruning. The déracinement (uprooting) by the Khmer Rouge would result in damaged roots, and decades of trauma to the people and the nation. The Khmer proverb, "Il faut planter le kapokier puis le palmier," embraces the process of rooting anew and rebuilding after destruction. In particular, the proverb refers to survival, as one must feign ignorance in order to survive. The figurative and literal meaning of the proverb implies the protection of Cambodian genealogy through the act of cultivation of the Kapok tree, the (sugar) palm tree, and eventually the rebuilding of Cambodia's culture and nation. Tian's family album-a survival tale of re-rooting-represents Cambodia's past and present traumas, and its regenerative identity.

The Khmer Rouge slogan and the old Khmer proverb reveal Cambodia's complex national identity, which may be defined by its (auto)destructive and self-preserving tendencies. First, it should be noted that under the Khmer Rouge, trees were converted into weapons and tools. The use of trees was deemed "a technique cheaper than using bullets," according to population geographer James Tyner: "During the genocide, the Khmer Rouge simply smashed infants and small children against trees-a technique cheaper than using bullets." 40 The transformation of the national tree of Cambodia, the sugar palm tree, daom thnaot [โพียรติด], into a killing machine is rendered on the cover of Volume 2, Ne vous inquiétez pas. Palm trees, alternated with the bright red Democratic Kampuchea flags, align the background of the cover. Two speakers are fastened to each palm tree, which represent how the trees now serve as an extension of Angkar's eyes, ears, and mouth. ${ }^{41}$ The Khmer Rouge slogans which are integrated into the album in capitalized letters, can thus be read as the diffusion of Khmer Rouge propaganda, slogans, songs, and orders through the nature-turned-machine sound systems. Moreover, the Khmer proverb, "Il faut planter le kapokier puis le palmier," which translates to the Three Wise Monkeys' maxim, "See no evil, hear no evil, speak no evil," may be read in parallel to the Khmer Rouge slogan, "L'Angkar a les yeux de l'ananas" [Angkar has the eyes of a pineapple]; the watchful eye of Angkar. In other words, the trees, which serve to amplify and transmit Angkar's orders, also become chlops [ญ్స్s\}], or child informants, used to report individual and transgressive acts—such as picking and pocketing fruit, vegetables, and flowers -to Khmer Rouge leaders.

\section{Cambodian Resilience and Rhizomatic Identity}

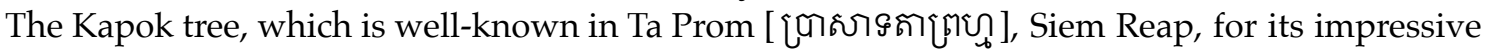
and invasive roots that weave their way into and over the historic temple illustrates the cyclical

\footnotetext{
36 Ben Kiernan, The Pol Pot Regime: Race, Power, and Genocide in Cambodia under the Khmer Rouge, 1975-1979, 2nd ed. (New Haven: Yale University Press, 2002), 8.

37 Ibid.

38 Chandler, The Tragedy of Cambodian History, 1.

39 Under the Khmer Rouge, family ties were prohibited: "The Khmer Rouge asked all Cambodians to believe, obey and respect only Angkar Padevat, which was to be everyone's 'mother and father.'" Dy, A History of Democratic Kampuchea, 2.

40 James A. Tyner, War, Violence, and Population: Making the Body Count (New York: The Guilford Press, 2009$), 2$.

41 See cover art in Tian's Ne vous inquiétez pas.
} 
and circular notion of death, which converges psychoanalytic theory and Buddhist philosophy. Post-1970s Cambodian identity, which is based largely on survival, complements critic Cathy Caruth's reflections on trauma, including the question of whether trauma is "the encounter with death, or the ongoing experience of having survived it." 42 The resilience of the Cambodian root systems also matches the survival story of Volume 1, Chapter 5, entitled "Il faut planter le kapokier, puis le palmier," as well as the three-volume Cambodian survival tale. The Kapok's roots, which simultaneously devour and maintain the structure of Ta Prom, illustrate French philosophers Gilles Deleuze and Félix Guattari's conceptualization of the anti-genealogical "rhizome," which "assumes very diverse forms, from ramified surface extension in all directions to concretion into bulbs and tubers." 43 Ta Prom serves to concretize the grandeur of the Khmer Empire, yet it also represents the entanglement of life and death, as the Strangler Fig and Banyan trees' root systems wrap around and make up the structure of the temple in Siem Reap, Cambodia. ${ }^{44}$ Rather than simply recycling the Khmer origin myth of past grandeur, however, Ta Prom and its root systems depict the inseparability of past, present, and future histories. The superimposition of life and death further illustrates the intertwining of histories and family relations, in the form of the cultivation of crops over the human remains from the Khmer Rouge regime. Southeast Asian anthropologist Anne Yvonne Guillou notes: "After the trauma of the Khmer Rouge regime, people gradually became more involved in making a living and rebuilding their lives. Rice fields and fruit trees were planted again over the mass graves, which symbolically meant that the life-cycle was starting again." 45 The Chan tree, which shares the author's site of birth and name, also shares a history with the Kapok's root system that symbolizes and defines Ta Prom-Chan's village natal. Furthermore, the Kapok's complex root systems complement the mangrove forests in Cambodia, which are also under threat, and demonstrate how Cambodian identity cannot be configured in the same way as a European family tree system. The national tree of Cambodia, daom thnaot [โพีษโตุตู], or Borassus flabellifer, and the California palm, Washingtonia filifera, represent Cambodian rhizomatic identity, which is largely shaped by displacement. Since the first wave of Cambodian immigration to America, the palm tree has doubled as a symbol for the Cambodian nation, as well as Cambodians of the Diaspora. ${ }^{46}$ In particular, Long Beach, California, the largest hub of Cambodian Americans, is integral to the Cambodian collective memory. ${ }^{47}$ Considering the complex root systems of the Kapok tree, and the Cambodian mangroves, as well as the displacement of Cambodians in the U.S., Canada, France, and Australia, uprooting proves to be a difficult, if not an impossible, task. Moreover, the unforeseeable effects of the Cambodian exodus following the Cambodian Genocide have muddled the boundaries of national, ethnic, racial, linguistic, and generational boundaries.

42 Cathy Caruth, Unclaimed Experience. Trauma, Narrative, and History (Baltimore: Johns Hopkins University Press, 1996), 7.

${ }^{43}$ Gilles Deleuze and Félix Guattari, A Thousand Plateaus: Capitalism and Schizophrenia, trans. Brian Massumi (Minneapolis: University of Minnesota Press, 1987), 6-7.

44 “Ta Prohm: Krong Siem Reap, Cambodia," Atlas Obscura, accessed June 19, 2019, https://www.atlasobscura.com/ places/ta-prohm/.

45 Anne Yvonne Guillou, "An Alternative Memory of the Khmer Rouge Genocide: The Dead of the Mass Graves and the Land Guardian Spirits [neak Ta]," in "Life After Collective Death in South East Asia: Part 1—The (Re-) Fabrication of Social Bonds," special issue, South East Asian Research 20 no. 2 (2012), 216.

46 For more information on Cambodia's national symbol, see Caroline Huot, "As National Symbol, Palm Trees Inspire Pride and Profit," The Phnom Penh Post, Oct. 24, 2003, accessed November 23, 2020, https:// www.phnompenhpost.com/national/national-symbol-palm-trees-inspire-pride-and-profit/.

${ }^{47}$ To further illustrate how the palm tree constitutes Cambodian identity and displacement, I offer my father's statement on re-rooting in California in the 1970s. While driving down the tree-lined streets in Los Angeles in 2008, he remarked that, the Californian palm trees, water, and warm climate reminded him of his childhood and hometown in Battambang, Cambodia. 


\section{Cambodian Displacement and Postmemorial Albums}

Postmemorial Cambodian family albums-or the creative art forms used to commemorate personal and family histories - are useful in activating memories, burying the ghosts of one's, or one's family's past, and burning one's own demons. While postmemorial albums conflate private and public memory, they primarily serve second-generation survivors. Unlike the physical cremation process, Cambodian family albums invite the successive generations to contribute to the endless memory-work by: a) transforming the postmemorial text/album itself through active participation, and b) constructing their own family albums in literary and art forms, such as film, graphic novel, essay, poetry, and music; what Cathy Schlund-Vials calls "Cambodian American memory work." 48 The reader, like the visitor of a memory-site or memorial contributes to the reconstruction of the text through her or his own presence and experience of the site/ text.

Chapter 5, "Il faut planter le kapokier puis le palmier," of Volume 1, Au revoir Phnom Penh offers a vignette of one of the many near-death encounters escaped by Tian's family. By the end of the chapter, the reader witnesses how Tian's family passes one of many survival testsby refusing to board a boat destined towards death. ${ }^{49}$ The narrative juxtaposes the inside and outside of a temple: In a single full-page panel, the reader looks straight on to the center of the page. The focal point, which takes up nearly half of the page, is the back of Buddha's head, which is recognizable by the etchings of carved stone and his long ear lobes. ${ }^{50}$ The reader takes on the perspective of Buddha, becoming his eyes and ears, and looking over the characters in the scene: The only ones that appear in color-in hues of purple-are the members of Tian's family, including baby Tian, lying in between his parents. Directly across from Buddha are the open doors that lead to two Khmer Rouge officials in all black. The faceless Khmer Rouge leaders are framed by the doors in front of them and by the two ends of the Pont des nagas (Naga Bridge) in the background. Upon closer observation, small splashes of red frame the photograph. To the upper left and upper right hand, red and white striped cones adorn the columns. A pair of small Buddhas is placed in the foreground-one to the left of the larger Buddha, and one to the right. What nearly goes unnoticed appears in the foreground, on the left and right shoulder of the Buddha overlooking the temple, and in-between the two smaller Buddhas. Despite being in the foreground, the following four characters appear hidden due to the focus on Buddha and the movement in the mid-ground and the background: A silent prayer ritual takes place, with the burning of incense. A man to the larger Buddha's left meets his eyes as he walks by, while three others-to Buddha's right-pray in silence. A man and a woman in a sampot (traditional Khmer garment, worn from waist to ankle), with her legs to her side, are in the middle of praying, while the other woman is knelt over facing the floor indicating that she is either at the start or the end of her prayer. Upon closer inspection, small touches of red appear in between the larger Buddha and the four characters. The straight lines, evenly spaced out between red specks, represent incense sticks and the process of duht tuup-to call on one's ancestors, to ask for protection, and/or to ask for forgiveness. In juxtaposition to this scene, the panels on the adjacent page depict the faceless Angkar, represented by the two Khmer Rouge officials at the edge of the entry and doorway, whose voice appears in the form of speech balloons shooting out from palm tree-audio systems. The funeral ritual depicted in this scene confronts the Khmer Rouge's takeover of Cambodian value systems and symbols. ${ }^{51}$ While the color red in the Cambodian context is often associated with the Khmer Rouge, its pre- and postDemocratic Kampuchean connection to traditional marriage ceremonies counters its symbol for communism, blood, and mass murder. What Cambodians refer to as a "Knot-Tying Ceremony" is an important step in Cambodian marriage rituals, in which family members and guests tie a

\footnotetext{
48 Cathy J. Schlund-Vials, War, Genocide, and Justice. Cambodian American Memory Work (Minneapolis: University of Minnesota Press, 2012), 16-17.

49 Tian, Au revoir Phnom Penh, 74-76; Veasna, Year of the Rabbit, 86-88.

50 Tian, Au revoir Phnom Penh, 68; Veasna, Year of the Rabbit, 80.

51 Ibid.
} 
red string ("blessing string") around the bride's wrist and the groom's wrist. The red string "blesses" the couple with good health and fortune, and must not be removed as it protects the couple from bad luck. The association of red with tradition and protection also appears in the form of offering incense, in the form of red batons, at the pagoda. Its subtle inscription within the middle of Volume 1, Au revoir Phnom Penh can thus be interpreted as an attempt to commemorate and protect Cambodia and its survivors. Moreover, the scene of prayer in the pagoda serves to reclaim the color red, which has since the Khmer Rouge regime become associated with communism, mass murder, and blood, through the association of the following: the red and white krama (traditional Khmer scarf) worn with the all-black uniform during the Khmer Regime; the red and yellow Democratic Kampuchea flag; and the Khmer Krahaam, or the

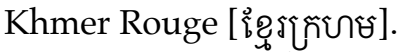

Up until the last chapter of Volume 2, Tian narrates the events of the Khmer Rouge as they unfold, starting from 1975. By dividing what feels like a series of never-ending and impossible tests of survival in the span of four years-into three volumes of seven chapters each - the text allows the reader to experience how time drags on and also witness the impossibility of surviving each test. This is why the album-souvenir at the end of Volume 2 is so surprising: Time equal to, or exceeding the amount, recounted in the three volumes collapses to a two-page spread selecting moments from a course of four years before 1975. What Tian labels an "Albumsouvenir avant 1975," at the close of Volume 2, Ne vous inquiétez pas includes a scrapbook of his unframed snapshots that were lost and/or never taken, arranged out of order, and meant to be offered and passed on to the next generation. The album-souvenir illustrates what life was like in Cambodia before the Khmer Rouge takeover of Phnom Penh: He presents a collage of his parents' marriage in Phnom Penh in 1974, his grand-uncle strumming an acoustic guitar, a snapshot of a traditional Khmer dance at the marriage ceremony, and his grand uncles in the middle of a game of hacky sack-le seï.52 Unlike the square-framed panels within the chapters, and like the family portraits in the family tree, the recreated photographs in the album-souvenir take the shape of an oval, resembling portraits intended to be framed as keepsakes. The photos pre-exist 1975-the event of his birth and the historicized start date of the Cambodian Genocide. The album-souvenir defies both the categorization of Tian's family history to the period of 19751979 and the reduction of Cambodian identity to the history of the Khmer Rouge regime. A couple of factors are useful towards reading the a-chronological organization of pre-1975 family photographs-Tian's age at the time of the takeover of Phnom Penh and his family's escape to France, and Tian's role as both a child survivor and a child of adult survivors. As noted earlier in this paper, in an interview with France Culture, Tian reveals that he recalls little of his childhood and that the 1984 film The Killing Fields ${ }^{53}$ enabled his parents to talk about the Khmer Rouge regime. Four years after having immigrated to Lyon, Tian's parents presented him with stories of his life in Cambodia, and their shared history under the Khmer Rouge regime. When asked how he was able to construct a graphic novel from an absence of memory, Tian remarks that after the release of The Killing Fields in France, his parents provided him with anecdotes about the Khmer Rouge, linked to his childhood: "Ils me parlaient des petites anecdotes sur les Khmers Rouges mais liées à mon enfance." [They told me about little anecdotes on the Khmer Rouge-but linked to my childhood. ${ }^{54}$ After the screening of The Killing Fields and asking his parents about their life in Cambodia, he engaged in a quest for knowledge of Cambodiabeyond the killing fields. 55 Tian's reflection on "l'histoire de [ses] parents" and Cambodia can be interpreted as a desire to remember and to understand what happened during the first few years of his life. Referring to his discovery of Cambodia's rich history, which was not only "linked to this tragic history," Tian states: "Quand j'ai découvert que c'était vraiment une

\footnotetext{
52 The "album-souvenir" is unnumbered; it immediately follows the final page of Volume 2. Tian, Un nouveau départ, page after 116; Veasna, Year of the Rabbit, page after 252.

${ }^{53}$ Roland Joffé, dir., The Killing Fields (Warner Brothers, 1984), 141 min.

54 Broué and Gardette, Cambodge, 01:12:12-01:13:16.

55 Ibid.
} 
grande civilisation avant, et puis que, par la force des choses, il a eu cette tragédie-là, je commençais quand même à réfléchir sur l'histoire de mes parents." [When I discovered that it was a great civilization before and then that by the force of things, it had this tragedy, I began to think about my parents' history. ${ }^{56}$ Rather than being read as out-of-order, the hand-drawn photos in the pre-1975 album may actually follow the order in which the histories were received.

While photographs predating 1975 occur within an album-souvenir at the end of Volume 2, an album of post-1980 memories is placed in the final pages of Volume 3. The multiplication of albums within the family album turns into an abyssal self-reflexivity, with the reproduction of L'année du lièvre, in two photographs of the third and final album, "Un nouveau départ après 1980."

Like Volumes 1 and 2, Volume 3 holds a 7-chapter narrative that sequentially elaborates on the 1975-1979 saga. Volumes 2 and 3 share the same layout-both are framed within family portraits and albums either preceding or following 1975-1979. Volume 3, in particular, offers an alternative account of life after 1975-1979. In other words, the Cambodian family album transforms into a postmemorial book and offers the reader a glimpse of 1.5- and secondgeneration postmemory. Initially, the family tree inscribed at the beginning of Volume 3 appears to be a replica of Khim and Lina's ${ }^{57}$ genealogical tree at the start of Volume 2. Upon closer inspection, however, Volume 3's tree signals to the reader who survived the genocide-and who did not-through the subtle fading out of certain family portraits juxtaposed with colored individual portraits hanging from the adjacent branches. ${ }^{58}$ Upon this discovery, the reader receives the residual affective hauntings transferred over from Tian and his ancestors. In addition, the post-Narrative scrapbook that closes Volume 3, "Un Nouveau départ après 1980," differs from the album-souvenir in Volume 2, and the 7-chapter narratives of the trilogy. For the first time, the family appears in motion. Left unframed, the family members-depicted in the bonus family album within the larger three-volume album-appear in conversation. Moreover, the transmission of histories occurs in the form of various mediums drawn by Tian, including a tape recorder, telephone, the exchange of family photos, direct oral transmission between characters, and even a replication of L'Année du lièvre. 59

Tian's use of the mise en abyme-what Lucien Dällenbach refers to as "the repetition within a work of 'the subject of the work' 'on the level of the character'"- - occurs within the graphic novel through his illustration of L'Année $d u$ lièvre in the third volume. ${ }^{60}$ In addition to recording his father's narration of the family history, Tian depicts his very own book, L'Année du lièvre, being passed down and shared with those depicted in the narrative. In order to illustrate Tian's album, which is placed into abyss, to literally translate the French term referring to the figure of style, I will present a verbal photograph of its insertion into the post-1980 album, "Un nouveau départ après 1980." On pages 2 and 3 of the book, the appearance of the physical album is passed along, in the hands of three family members: 1) Tian's mother, Lina, whom he addresses as "Maman," 2) One of his maternal uncles, or one of Lina's brothers-either Uncle Koliane, or Uncle Samay, and 3) Tian's maternal grandmother, Vanny, whom he addresses

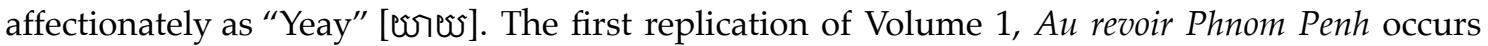
on the second page, in which Tian, now an adult, stands to the right of his mother. Dressed in a bright red, long sleeved and collared shirt, he asks, "Alors maman, tu l'as lu?" (So Mother, have

\footnotetext{
56 Ibid., 01:14:22-01:14:38.

57 The author's father and mother, Khim and Lina, are shown deciding whether or not to abandon their photo album, before fleeing Phnom Penh. Tian, Au revoir Phnom Penh, 19; Veasna, Year of the Rabbit, 31.

58 The family trees are included in the front matter of volumes 2 and 3, in the original French edition. In the English edition, the first family tree follows the preface, and the second family tree follows the postface. Note: These pages are unnumbered in both editions.

59 The pages in "Un nouveau départ après 1980," (in English: "A New Beginning—1980 and beyond") are unnumbered. See Tian, Un nouveau départ, page after 110. Veasna, Year of the Rabbit, page after 368.

${ }^{60}$ Lucien Dällenbach and Annette Tomarken, "Reflexivity and Reading," New Literary History 11, no. 3 (1980), 436, accessed October 29, 2020, https:// doi.org/10.2307/468937.
} 
you read it?) Lina, dressed in a patterned lilac shirt, and what appears to be-from the half of her body depicted-a Khmer sampot, responds by stating that she could not advance beyond the third chapter. Upon closer inspection, the mother-and-son portrait captured by the author resembles the cover of Volume 1 itself. The "original" cover depicts Lina in the same patterned lilac shirt, which ends above her hips and slightly surpasses her biceps on the cover. ${ }^{61}$ Yet, now that Lina and the shirt has aged, the sleeves reach her lower biceps. Though Tian is depicted as a baby in his mother's arms on the front cover, he resembles his father, Khim, in the handdrawn photograph of him in conversation with his mother. On the cover of Volume 1, his father is turned away, looking off to the right. The reader thus receives a still frame of his family on the day of the takeover of Phnom Penh and a profile shot of his father's right side. Tian, in conversation with his mother, is also turned to the right, presenting the reader with a view of the right side of his face. He shares with his father a prominent nose, from his profile, as well as the same noticeable bangs swept upward in the direction of his gaze. Like Tian, his father is dressed in a long-sleeved shirt, which is left unbuttoned at the neck, forming a V-neck shirt and tucked into blue jeans. Khim's style of dress in 1975, seen on the cover of Volume 1, matches Tian's clothing, which is depicted in a borderless panel in "Un nouveau départ après 1980" in Volume 3.62 The subsequent page in "Un Nouveau départ après 1980" depicts, in the upper lefthand corner, a scene in which Tian presents his maternal grandmother and uncle each with a copy of L'Année du lièvre. ${ }^{63}$ Though the cover is difficult to decipher in the snapshot, it appears to be Volume 1-based on the silhouette of smoke drawn in on the cover of the book held between his grandmother's hands. Tian stands in the middle of one of his uncles (Uncle Koliane or Uncle Samay), and his grandmother, who is seated partially upright in a reclining bed. In addition, he finds himself between two of the replicas of L'Année du lièvre, pointing to a picture in the album that his Yeay holds in her hands. While the reader does not see the picture, it is implied that the photo is self-referential, and one from the "album-souvenir avant 1975," as Tian remarks: "Yeay, je t'ai dessinée avec Ta dans votre maison..." [Grandma, I drew you with Grandpa, in your home... $]^{64}$

The mise en abyme of the album illustrates the active and creative quality of postmemory. In addition to the replication of albums depicted in the pages of L'Année du lièvre, the author circulates and transmits the family narrative that he received from his parents in the 1980s. The act of transmitting the narrative, in the form of the graphic novel, back to the original "actors" of the history, serves first to confront the family silences and to prevent perpetuating the unconscious transmission of family trauma, then to demonstrate how first-generation testimony is a collaboration of first and 1.5- or second-generation encounters. It should be noted that the collaborative memory work between Tian and his parents begins with a family discussion, following the release and the screening of The Killings Fields in 1984. Yet, the discussion is endless-described by Tian as coming one-after-the-other; linked to one another [ $\mathrm{s}^{\prime}$ enchaîner]:

${ }^{61}$ See cover art for Volume 1, Au revoir Phnom Penh. See also, Tian, Un nouveau départ, third page after 110; Veasna, Year of the Rabbit, third page after 368.

62 Ibid. Khim's clothing in Volume 1, particularly his denim jeans, characterizes him as the "new people," in juxtaposition to the "old people" in Democratic Kampuchea: "The Khmer Rouge were determined to turn the country into a nation of peasants and workers in which corruption, feudalism and capitalism could be completely uprooted." Dy, A History of Democratic Kampuchea, 16. See also, Ibid., 47: "Nearly everyone who was known to be well educated was put to death. No one dared to wear glasses or speak foreign languages; it was a sign that they were educated. Many urban Cambodians, in particular, had to conceal their past and their talents, and pretend to be illiterate." Volume 2 begins by showing the reader the route traveled by Khim and Vithya (Khim's uncle) from Phnom Penh to Roneam: "After their arrest by Khmer Rouge militia, Khim and Vithya's families were sent to a village to be reeducated according to the principles of Angkar." Veasna, Year of the Rabbit, 138; Tian, Ne vous inquiétez pas, 2. Khim's wardrobe change from Volume 1 to Volume 2-from jeans into an all-black, long-sleeved shirt and pants, with a checkered red-and-white krama-signals a transformation of Cambodia into Democratic Kampuchea. See Veasna, Year of the Rabbit, 141; Tian, Ne vous inquiétez pas, 2-5. For a representation of the "new people," see Veasna, Year of the Rabbit, 188; Tian, Ne vous inquiétez pas, 52.

${ }^{63}$ Tian, Un nouveau départ, fourth page after 110; Veasna, Year of the Rabbit, fourth page after 368.

64 Ibid. 
"Je commençais quand même à réfléchir sur l'histoire de mes parents. Donc, il y a eu au départ une petite, euh, une discussion, puis, après, ça s'est enchaîné..." [I started to reflect on my parents' history/story. So, there was, at first, a little discussion, and then, after, things came one after another...]65

Finally, the role of the tape recorder represents the conflation of past and present, and of first- and second-generation memory. The Franco-Cambodian tape recorder mirrors the shared history between father and son in Spiegelman's Maus. Hirsch notes the following: "Vladek talks into a tape recorder and Art asks him questions, follows up on details, demands more minute descriptions. The testimony is contained in Vladek's voice, but we receive more than that voice; we receive Art's graphic interpretations of Vladek's narrative."66 Tian's graphic novel is different as the recorder appears only once, at the end of the trilogy, within the six-page surplus album, "Un nouveau départ après 1980." In Tian's case, the tape recorder appears in a single panel, at the end of the trilogy, within the surplus album, after the 1975-1979 narrative. Moreover, the three-volume novel includes more than his father's direct testimony-but also his mother's inability to read her son's rendition of their lived experiences in Cambodia. Yet, the trilogy closes with the post-1980 album, which begins with a visual-verbal, or photographic, reproduction of the start of his family's oral narrative. The simple display of the recorder, and the conversation between father and son in the 1980s represented by speech balloons without lines represents the fragmentary nature of testimony. Moreover, the recording, which is "played" and/or shared with the reader decades later in 2016, within the third volume of L'Année du lièvre, follows the structure of Cambodian oral narratives-characterized by nonlinear narration, digressions, and repetition. Tian's album thus closes with a verbal-visual photograph of a return to oral narration that mirrors the circular and cyclical aspect of Cambodian storytelling.

By the end of the trilogy and on the last page of "Un nouveau départ après 1980," the reader witnesses a still frame of Tian and his son, and the transmission of history, orally, from father to son. Tian (Chan Veasna) indicates to the reader: "Chan est devenu papa à son tour et pour transmettre son histoire, il parle du Cambodge à son fils." [Chan became a father, himself, and in order to transmit his history, he tells his son about Cambodia.] With their eyes locked, his son exclaims in a speech balloon, "Papa! Un jour j'irai dans ton pays, le Cambodge!" 67 The album thus closes with the intersection of first-, 1.5-, second-, and third-generation memories and dialogues. Moreover, his son's last words allude to two things: The stress on the possessive adjective, ton, or "your," paired with the substantive, pays, or "country," subtly reveals the complexity of second- and third-generation identity. While many second- and third-generation Cambodians of the diaspora are immersed in their parents' culture, language, and history, a distance and gap remains, and a desire to "know the world of [their] parents" dominates. ${ }^{68}$ In addition, the fact that Chan's (Tian) son has the last say in the trilogy alludes to the Cambodian diasporic literary-arts and new aesthetics movements, in flux, and in the process of being created and recreated. This endless movement of memory, and postmemorial work, is evident on the cover of Volume 3, Un Nouveau départ, and within the album. The final page of the album presents a panorama of Phnom Penh shot from above with the author's remarks on the present and future of Phnom Penh. In three paragraphs, Tian reflects on the economic development and changes in the capital, commenting on the conflation of tourism and the Khmer Rouge Tribunal in the 21st century.

\footnotetext{
${ }^{65}$ Broué and Gardette, Cambodge, 01:14:34-01:14:52.

${ }^{66}$ Hirsch, Family Frames, 12.

${ }^{67}$ English translation: Papa, I want to go to Cambodia to see your country! See Tian, Un nouveau départ, seventh page after 110; Veasna, Year of the Rabbit, seventh page after 368.

${ }^{68}$ Hirsch, Family Frames, 245.
} 
Beyond the Graphic Novel: Cambodian New Aesthetics and the Personal-Collective Archive Returning to Deleuze and Guattari's characterization of the "rhizome," Cambodian identity may be interpreted as growing endlessly in various directions: The conjunction of Cambodian displacement following the 1970s, the "new" identities born in and beyond Cambodian communities in France, Canada, the U.S., and Australia, and the urbanization of Phnom Penh in the late 20th and 21st centuries, emphasize the difficulty of defining Khmer identity. Turning to the cover of Volume 3, which illustrates Tian's family in displacement, the reader notes that what appear to be branches are actually Kapok roots. The roots resurface-bursting from the center of the temple and its rubble, and also appearing in Lina's left hand. Lina can be seen sweating, following behind Tian and Khim, and holding the roots for balance. Enveloped by trees, Tian and his parents, Lina and Khim, and two others are shown walking atop a temple. In juxtaposition to the first album cover, which depicts the family frozen in fear and turned in the opposite direction of the incoming traffic, the cover of the third and final album, Un Nouveau départ, shows the family in movement, rushing forward towards what is out of frame, and imperceptible to the reader. In addition, Tian is pictured as an infant, asleep on Khim's back. The representation of child survivor Tian as asleep and facing forward evokes the activation of 1.5- and second-generation dormant memories. Moreover, the snakelike roots bursting from the temple that provide Lina balance illustrate Cambodian rhizomic identity, which is endlessly transforming itself upon the mixing and merging of the diverse memories of Cambodians across various generations, locations, and experiences.

This article concludes with a definition of Cambodian rhizomatic identity and Cambodian ontology - beyond the comics medium, generational and geographical boundaries, and the genealogical notion of family. The postmemorial family album is derived from Hirsch's conceptualization of the "aesthetics of postmemory," which she defines as "a diasporic aesthetics of temporal and spatial exile that needs simultaneously to (re)build and mourn." 69 In addition, this section examines Cambodian identity in relation to the potentiality of rupture, as well as the evolving and collaborative quality of the rhizome. ${ }^{70}$ Postmemorial aesthetics also resonate with Martinican philosopher Edouard Glissant's concepts "creolization" and "identitérhizome," which emphasize the multiplicity of cultures, identities, and timelines: "Instead of electing one past, these Caribbean civilizations build a functional métissage, situated in the present ('today') and branching out to an open-ended future."71 The aspect of creolization is useful in understanding the relation between Cambodian identity and 21st century diasporic artistic production. Like the overlapping of past, present, and an open-ended future, first-, 1.5-, second, and third-generational memories converge. The entanglement of memories leads to new artistic possibilities. Such art forms demonstrate the creative potentiality of displacement and fragmentation-as characterized by Deleuze and Guattari's principle of asignifying rupture: "A rhizome may be broken, shattered at a given spot, but it will start up again on one of its old lines, or on new lines."72 Postmemorial aesthetics chooses the latter, interacting with old lines to form new possibilities. In the case of Cambodian new aesthetics, pre-Democratic

${ }^{69}$ Ibid.

${ }^{70}$ Deleuze and Guattari, A Thousand Plateaus, 9-11. See also Valérie Loichot, "Between Breadfruit and Masala: Food Politics in Glissant's Martinique," Callaloo 30, no. 1 (2007), 134, accessed June 18, 2019, https://doi.org/10.1353/ cal.2007.0151.

${ }^{71}$ Loichot, Between Breadfruit and Masala, 129. On métissage, and the untranslatability of the word, see Françoise Lionnet, Autobiographical Voices: Race, Gender, Self-Portraiture (Ithaca: Cornell University Press, 1999), 13. "The word does not exist in English: one can translate métis by 'half-breed' or 'mixed-blood' but these expressions always carry a negative connotation, precisely because they imply biological abnormality and reduce human reproduction to the level of animal breeding." The meaning of métissage, here, goes beyond-what Martinican philosopher and theorist Edouard Glissant's considers-a mathematical logic that produces predictable categories. Like his concept of créolisation, it refers to l'imprévisible [the unpredictable]; the potentiality of incalculable and unforeseeable exchanges. See Edouard Glissant, "Métissage et créolisation," in Discours sur le métissage, identités métisses: En quête d'Ariel, ed. Sylvie Kandé (Paris: L'Harmattan, 1999), 49-51.

72 Deleuze and Guattari, A Thousand Plateaus, 9. 
Kampuchea forms of art are restored, preserved, and reimagined. Asian American scholar Khatharya Um demonstrates the fragmentary yet continuous quality of second-generation memory through the metaphor of a broken chain.

The metaphor of a 'broken chain' [depicts] the sense of discontinuities that all of us refugees feel in our lives-the physical loss, the sense of dislocation and displacement, the disruption, rupture and loss in cultural transmission based as it is so much on oral tradition, the absence of closure; many of us have no way of knowing what happened to our loved onesonly that they had disappeared. There can be no marker of remembrance save on mass graves. Despite the severance-in the historical, in the generational, in the cultural sense-there is something fundamentally innate that continues to bind us as a refugee generation. Perhaps for many of us, the warespecially within ourselves-is far from over. ${ }^{73}$

It should be noted that while rupture activates the creative component of postmemory, it can never be completely full, nor should it seek to be. However, this shared sense of loss-combined with the overlapping of timelines and trans-generational memories-contributes to forming a cohesive sense of identity in second-generation survivors. This fragmentary yet cohesive quality of postmemory thus illustrates the Cambodian family album, or "book designated for sticking pictures." The creative aspect of rupture can also be visualized through 1.5-generation Vietnamese artist Binh Danh's chlorophyll prints of S-21, or Tuol Sleng prisoners in Phnom Penh. ${ }^{74}$ The artist manipulates organic and manmade materials-using leaves, resin, and sunlight-to recreate prisoners' photographs. The 2006 exhibit, "Ancestral Altars," which was held in the Haines Gallery in San Francisco, California, nods to the French technological influences, borrowed and practiced by the Khmer Rouge, in the form of archiving "criminal" daguerreotypes. In addition, the chlorophyll and resin recreation of S-21 portraits allude to the re-appropriation of the space that held the prisoners: What served as a high school to Cambodian students prior to April 17, 1975 transformed into one of the deadliest prisons-S-21, under the Khmer Rouge regime from 1975 to 1979-and into a museum, in 1979, used to document the Khmer Rouge atrocities during the Vietnamese Occupation of Cambodia. Danh's exhibit thus captures the transnational and trans-generational component of postmemorial art, and also demonstrates the imaginative and creative quality of loss.

The interlacing of absence and excess, and rupture and suture, should be considered in relation to the growth of artistic production by members of the second-generation of Cambodian genocide survivors. ${ }^{75}$ The surge in postmemorial art serves multiple purposes: to examine and to express one's hybrid identity in multiple "ethnic" or transnational forms, and to connect and discover one's history through the creative artistic process. The new aesthetics of Cambodian postmemory, like the Khmer sampot [ல̛ำ่] and krama [โกยฮ], embody the mixedness and intersection of old and new. In particular, their composition and role as cultural and national symbols vary across time and space and undergo continual change. In the case of the krama, the quotidian accessory transformed into a symbol associated with the Khmer Rouge regime-as depicted in Tian's L'Année du lièvre through the black uniforms paired with red and white checkered kramas. Yet, it is the sampot-the "national garment of Cambodia" —an

\footnotetext{
${ }^{73}$ Khatharya Um, "Specificities: The Broken Chain: Genocide in the Re-Construction and De-struction of Cambodian Society," Social Identities 4, no. 1 (1998), 152, accessed May 5, 2020, https:// doi.org/10.1080/13504639851924.

74 Binh Danh, Ancestral Altars, 2006, Haines Gallery, San Francisco, CA, exhibition catalogue.

75 "Being un-sutured involves a continuous process of renewal and commitment." George Yancy, ed., White SelfCriticality beyond Anti-racism: How Does it Feel to be a White Problem? (Lanham: Lexington Books, 2014), 5-6. For examples of "suturing" and "un-suturing," see also, ibid., 8-11.
} 
aesthetic form itself that demonstrates the postmemorial generation's contributions to rebuilding and shaping Cambodian-ness. ${ }^{76}$ From its intricate weavings to its various styles and the innumerable ways to fold it, the sampot represents what Roger Nelson refers to as a "hybrid contemporaneity." 77 Interpreting Cambodian artist Chan Dany's exhibit, "Sampot: The Collection of Small Things," Nelson remarks the "multiplicity of contemporaneity in Cambodia," adding: "A vision of Cambodia emerges that is at once old and new, local and global. The articulation of contemporaneity refuses the dominant narrative about nation, centered on the temples of Angkor Wat and the traumas of the Khmer Rouge. Yet it also resists the tendency to overlook or downplay historical continuities."78

Though the Cambodian family album must be considered beyond the comics medium, it is worth noting the history of Cambodian comics, which continues to be shaped by French and Belgian influences. The first Cambodian comic book is credited to Khmer cartoonist Uth Roeun in the 1960s: His popular comic based on the Cambodian trickster Torn Chey circulated widely in Cambodia in the 1980s and continues to be read by Cambodians of the diaspora. ${ }^{79}$ Despite having lanced the graphic novels scene in Cambodia, his advice to Cambodian artists, "[d]on't write about killing and war," has been largely disregarded, as illustrated by Tian and Séra's representations of genocide in the graphic novel..$^{80}$ The 21st century Cambodian arts scene can thus be understood as a creative process born from the intersection of Cambodia's past colonial and Khmer Rouge histories, and the collaborative efforts of "local" Cambodian and diasporic Cambodian communities.

The continued displacement of Cambodians-including the movement of Cambodian Americans from the U.S. to Cambodia-illustrates the unpredictable and transnational aspect of Cambodian new aesthetics. Cambodian American prison poet Kosal Khiev-who was born in the Khao-I-Dang refugee camp in 1980, raised in California, served time in the U.S. prison system, and deported to Cambodia in 2011-is representative of the group of Cambodian American refugee deportees. ${ }^{81}$ This sudden expulsion is particular as it causes 1.5- and secondgeneration Cambodians to experience arguably the most traumatic aspect of "postmemory," which is "the condition of exile from the space of identity." 82 What was once considered the world of their parents-one which they sought to understand but could never fully knowbecomes their own. Khiev's spoken word poetry affectively communicates this sense of lossand documents his experiences of navigating and rediscovering Cambodian language, culture, and identity. ${ }^{83}$ Crisis and exile is conveyed through a new aesthetic in flux with the displacement of second-generation Cambodians-whether by choice or through forced exile.

French film director Denis Do also communicates historical elements of the Khmer Rouge regime through the medium of animated film. Do's film, Funan, also serves to examine his Franco-Sino-Cambodian identity. ${ }^{84}$ Funan depicts the personal and collective events of the Khmer Rouge regime as experienced by his mother, Chou. The medium is arguably more accessible to viewers-as scenes of graphic violence are never fully visible to the audience.

\footnotetext{
76 Jonathan H. X. Lee and Kathleen M. Nadeau, eds., Encyclopedia of Asian American Folklore and Folklife, Vol. 1 (Santa Barbara: ABC-CLIO, 2010), 188; Hirsch, Family Frames, 242-243.

77 Roger Nelson, "On the Coevalities of the Contemporary in Cambodia: Review: Sampot: The Collection of Small Things by Chan Dany," Contemporaneity: Historical Presence in Visual Culture 3, no. 1 (2014), 201, accessed June 5, 2019, https://doi.org/10.5195/ contemp.2014.87.

78 Ibid., 206.

79 John A. Lent, Asian Comics (Jackson: University Press of Mississippi, 2015), 120.

80 Ibid., 122

81 Charles Dunst, “Cambodian Deportees Return to a 'Home' They've Never Known," The Atlantic, Jan. 16, 2019, accessed November 23, 2020, https://www.theatlantic.com/international/archive/2019/01/america-deportscambodian-refugees/580393/.

82 Hirsch, Family Frames, 243.

83 Masahiro Sugano, dir., Cambodian Son (Studio Revolt, 2014), 90 minutes.

84 Denis Do, dir., Funan (Bac Films, 2018), 84 minutes.
} 
Rather, scenes of rape and murders are implicit. ${ }^{85}$ For instance, gunfire is heard and reflected in the form of bright flashes on Chou's face. ${ }^{86}$ In addition, the film follows a non-linear form and illustrates how memories are "filled in," in the form of blank spaces which slowly become saturated with pigment: When Chou's son, Sovanh, is separated from his parents, the audience experiences the young boy's daydream, in which he re-experiences his birthday with his parents. A white space takes over the screen; Sovanh appears smiling in a birthday hat, then one-by-one, his parents are drawn in. ${ }^{87} \mathrm{Do}^{\prime}$ s conscious sensitivity to the sights and sounds-and the pacing of the narrative-allow the viewer to participate as a willing witness.

The Cambodian new aesthetics is perhaps best exemplified through Long Beach, California-born and Cambodian ex-patriot choreographer Prumsodun Ok's artistic renderings. Since 2017, Prumsodun Ok \& Natyarasa, Cambodia's first all-male and LGBTQ dance production, has been reshaping Cambodian identity through a contemporary take on Khmer classical dance. ${ }^{88}$ In their performance, Vajramala: Spirit of Khmer Dance, dancers perform to traditional Khmer music as well as "foreign" and popular contemporary music, such as UK singer-songwriter Sam Smith's 2014 hit song, Lay Me Down. ${ }^{9}$ Ok's contributions to the arts has allowed for inclusivity within the dance world-as prior to 2017, Khmer classical dance was comprised of a predominantly female cast, with Cambodian Princess Buppha Devi in the Cambodian imaginary. ${ }^{90}$ His revival of Khmer classical dance serves to preserve a once dying art and narrative form, which faced near annihilation during the Khmer Rouge regime. More importantly, Ok revamps a traditional aesthetic form, and in doing so, he calls for a more fluid definition of Khmer-ness beyond a monolithic and genealogical model.

The creative aspect of postmemory-always in movement-allows one to become an active subject rather than an inactive viewer or listener. The 21st century processes of remembering, mourning, and (re)creating in the Cambodian diaspora demonstrate postmemory work, which exchanges with, and builds off of first-generation memory. The purpose of the Cambodian new aesthetics is not to fully recover memory; nor does it function to reconstruct the past. Rather, it serves as a testimony to the experience of second-generation Cambodian genocide survivors and demonstrates how 21st century Cambodian identity moves beyond national and generational boundaries. In closing, it must be noted that while the Khmer and Buddhist form of mourning is circular, the Cambodian postmemorial album attempts to break the cycle of the unconscious transmission of trauma by actively involving the subsequent generations in the process of mourning.

\section{Bibliography}

Atlas Obscura. "Ta Prohm: Krong Siem Reap, Cambodia." Accessed June 19, 2019. https:// www.atlasobscura.com/places/ta-prohm/.

Baker, Margaret P. “The Rabbit as Trickster,” Journal of Popular Culture 28, no. 2 (1994), 149-158.

\footnotetext{
85 Ibid., 01:00:54-01:01:11. The viewer witnesses a scene of dangling feet, implying suicide by hanging. This immediately follows a scene depicting a young girl's (Lily) sexual assault—which is never explicitly represented. Ibid., 00:57:1200:59:46.

86 The gunfire is audible and reflected on Chou's face. See Ibid., 01:05:44-01:05:47. The incident follows the exchange of dialogue between an armed Khmer Rouge soldier and an old woman. "Vous allez voir ce qu'Angkar réserve aux ennemis de la Révolution!" [You'll see what Angkar has in store for enemies of the Revolution]_-Pitié! Je n'ai rien fait!" [Mercy! I didn't do anything!]. See Ibid., 01:05:39-01:05:44.

87 Ibid., 00:36:58-00:37:19.

88 Vajramala: Spirit of Khmer Dance, dir. Pumsodun Ok. Counterspace Theater at Java Creative Café in Tuol Tompung, Phnom Penh, January 6, 2019. Live performance.

${ }^{99}$ Sam Smith, “Lay Me Down," track 10 on In the Lonely Hour (standard edition), Capitol, 2014, CD.

90 "When Princess Buppha Devi turned eighteen in 1961, she was appointed the lead dancer for princess roles in the Royal Ballet and performed in important diplomatic events in Cambodia and abroad." See Suppya Hélène Nut and Boreth Ly, "Princess Norodom Buppha Devi (1943-2019): A Life in Dance," Asian Theatre Journal 37, no. 2 (2020), 313, accessed Nov. 15, 2020, https:// doi.org/10.1353/atj.2020.0031.
} 
Broué, Caroline and Hervé Gardette. "Cambodge." September 14, 2011. In France Culture, Podcast. 87 minutes. Accessed November 9, 2020. https://www.franceculture.fr/ emissions/la-grande-table-1ere-partie/cambodge.

Caruth, Cathy. Unclaimed Experience: Trauma, Narrative, and History. Baltimore: Johns Hopkins University Press, 1996.

Chandler, David. The Tragedy of Cambodian History: Politics, War, and Revolution since 1945. New Haven: Yale University Press, 1991.

Chute, Hillary L. Disaster Drawn: Visual Witness, Comics and Documentary Form. Cambridge: Belknap Press, 2016.

Danh, Binh. Ancestral Altars, 2006. Haines Gallery, San Francisco. Exhibition Catalogue.

Dällenbach, Lucien, and Annette Tomarken. "Reflexivity and Reading." New Literary History 11, no. 3 (1980), 435-449. Accessed October 29, 2020. https: / / doi.org/10.2307/ 468937.

Deleuze, Gilles, and Félix Guattari. A Thousand Plateaus. Capitalism and Schizophrenia. Translated by Brian Massumi. Minneapolis: University of Minnesota Press, 1987.

Do, Denis, dir. Funan. Bac Films, 2018.

Dunst, Charles. "Cambodian Deportees Return to a 'Home' They've Never Known," The Atlantic, Jan. 16, 2019. Accessed November 23, 2020. https://www.theatlantic.com/ international/archive/2019/01/america-deports-cambodian-refugees/580393/.

Dy, Khamboly, A History of Democratic Kampuchea (1975-1979). Phnom Penh: Documentation Center of Cambodia, 2007.

El Refaie, Elisabeth. Autobiographical Comics: Life Writing in Pictures. Jackson: University Press of Mississippi, 2012.

Felman, Shoshana and Dori Laub. Testimony: Crises of Witnessing in Literature, Psychoanalysis, and History. London: Routledge, 1991.

Glissant, Edouard. "Métissage et créolisation," in Discours sur le métissage, identités métisses: En quête d'Ariel, edited by Sylvie Kandé, 47-53. Paris: L'Harmattan, 1999.

Guillou, Anne Yvonne. "An Alternative Memory of the Khmer Rouge Genocide: The Dead of the Mass Graves and the Land Guardian Spirits [neak Ta]." In "Life After Collective Death in South East Asia: Part 1-The (Re-)Fabrication of Social Bonds." Special Issue. South East Asia Research 20, no. 2 (2012), 207-226. http://www.jstor.org/stable/ $\underline{23752538 .}$.

Harris, Ashleigh. "Speaking the 'Truth' by Dissembling': Necessary Ambiguities in the Tar-Baby Tale." Journal of Literary Studies (Pretoria, South Africa) 16, no. 3-4 (2000), 58-75. Accessed Nov. 13, 2020. https:// doi.org/10.1080/02564710008530265.

Hirsch, Marianne. Family Frames: Photography, Narrative, and Postmemory. Cambridge: Harvard University Press, 1997.

Huot, Caroline. "As National Symbol, Palm Trees Inspire Pride and Profit." The Phnom Penh Post, Oct. 24, 2003. Accessed November 23, 2020. https://www.phnompenhpost.com/ national/national-symbol-palm-trees-inspire-pride-and-profit/.

Jacob, Judith M. The Traditional Literature of Cambodia: A Preliminary Guide. Oxford: Oxford University Press, 1996.

Joffé, Roland, dir. The Killing Fields. USA: Warner Brothers, 1984. Videodisc.

Kiernan, Ben. The Pol Pot Regime: Race, Power, and Genocide in Cambodia under the Khmer Rouge, 1975-1979, 2nd ed. New Haven: Yale University Press, 2002.

Kunka, Andrew J. Autobiographical Comics: Life Writing in Pictures. New York: Bloomsbury Academic, 2018.

Laurent, Caroline D. 2019. "(Re)creating the Past: Representations of Cambodia in Francophone Sequential Art." Panel discussion at the 14th Biennial Conference of the International Association of Genocide Scholars, Phnom Penh, Cambodia, July 14-19, 2019.

Lee, Jonathan H. X. and Kathleen M. Nadeau, eds. Encyclopedia of Asian American Folklore and Folklife, Vol. 1. Santa Barbara: ABC-CLIO, LLC, 2010.

Lent, John A. Asian Comics. Jackson: University Press of Mississippi, 2015. 
Lionnet, Françoise. Autobiographical Voices: Race, Gender, Self-Portraiture. Ithaca: Cornell University Press, 1999.

Loichot, Valérie. "Between Breadfruit and Masala: Food Politics in Glissant's Martinique." Callaloo 30, no. 1 (2007), 124-137. Accessed June 18, 2019. https://doi.org/10.1353/ cal.2007.0151.

Nelson, Roger. "On the Coevalities of the Contemporary in Cambodia: Review: Sampot: The Collection of Small Things by Chan Dany." Contemporaneity: Historical Presence in Visual Culture 3, no. 1 (2014), 193-207. Accessed June 5, 2019. https://doi.org/10.5195/ contemp.2014.87.

Norindr, Panivong. "The Sounds of Everyday Life in Rithy Panh's Documentaries." French Forum 35, no. 2-3 (2010), 181-190. Accessed October 29, 2020. https://doi.org/10.1353/ frf.2010.0004.

Nut, Suppya Hélène and Boreth Ly. "Princess Norodom Buppha Devi (1943-2019): A Life in Dance," Asian Theatre Journal 37, no. 2 (2020), 311-327. Accessed November 15, 2020. https://doi.org/10.1353/atj.2020.0031.

Panh, Rithy, director. L'Image manquante. France: ARTE Éditions, 2013. Film.

Ponchaud, François. Cambodge, Année Zéro: Document. Paris: Julliard, 1977.

Sak-Humphry, Chhany. Tales of the Hare: 27 Classic Folktales from Cambodia, edited by Kent Davis. Holmes Beach: DatASIA, 2010.

Satrapi, Marjane. Persepolis. Paris: L'Association, 2000.

Schlund-Vials, Cathy J. War, Genocide, and Justice. Cambodian American Memory Work. Minneapolis: University of Minnesota Press, 2012.

Séra. Concombres amers: les racines d'une tragédie, Cambodge, 1967-1975. Vanves: Marabout, DL, 2018.

---------. Impasse et rouge. Paris: Albin Michel, 2003.

L'eau et la terre: Cambodge, 1975-1979. Paris: Delcourt, 2005.

. Lendemains de cendres: Cambodge, 1979-1993. Paris: Delcourt, 2007.

Smith, Sam. "Lay Me Down." Track 10 on In the Lonely Hour (Standard Edition), Capitol, 2014, CD.

Spiegelman, Art. Maus I: A Survivor's Tale: My Father Bleeds History. New York: Pantheon, 1986.

------. Maus II: A Survivor's Tale: And Here My Troubles Began. New York: Pantheon, 1991.

Sugano, Masahiro, dir. Cambodian Son. Studio Revolt, 2014.

Suleiman, Susan Rubin. "The 1.5 Generation: Thinking About Child Survivors and the Holocaust." American Imago 59, no. 3 (2002), 277-295.

Tian. L'Année du lièvre. Au revoir Phnom Penh. Paris: Gallimard, 2011.

---------. L'Année du lièvre. Ne vous inquiétez pas. Paris: Gallimard, 2013.

-------. L'Année du lièvre. Un nouveau départ. Paris: Gallimard, 2016.

Tran, GB. Vietnamerica: A Family's Journey. New York: Villard Books, 2010.

Tyner, James A. War, Violence, and Population: Making the Body Count. New York: The Guilford Press, 2009.

Um, Khatharya. "Specificities: The Broken Chain: Genocide in the Re-Construction and Destruction of Cambodian Society." Social Identities 4, no. 1 (1998), 131-154. h t t p s : / / doi.org/10.1080/13504639851924.

Veasna, Tian. Year of the Rabbit. Montreal: Drawn and Quarterly, 2020.

Veld, Laurike in 't. The Representation of Genocide in Graphic Novels: Considering the Role of Kitsch. Cham: Palgrave Macmillan, 2019.

Yancy, George, ed. White Self-Criticality beyond Anti-racism: How Does it Feel to be a White Problem? Lanham: Lexington Books, 2014.

. The Texture of Memory. Holocaust Memorials and Meaning. New Haven: Yale University Press, 1993. 